\title{
Effect of partially replacing fish meal by poultry by-product meal on growth performance and feed utilization of European eels, Anguilla anguilla (Linné 1758)
}

\author{
El- Hussieny O.M. ${ }^{1}$; Goda A.M.A-S. ${ }^{*}$; Mabroke R.S. ${ }^{1}$ and Ghonimy A.M.A. ${ }^{2}$ \\ ${ }^{1}$ Animal production department, Faculty of agriculture, Cairo University, Egypt \\ ${ }^{2}$ Fish Nutrition Laboratory, National Institute of Oceanography and Fisheries (NIOF), Cairo, Egypt
}

\begin{abstract}
A 60-days feeding study was conducted to evaluate the effect of partial substitution $(0,20,40$ and $60 \%)$ of dietary fish meal (FM) with poultry by-product meal (PBM) on growth performance and feed utilization of European elver eels, Anguilla anguilla. A total of 80 A. anguilla with an average initial weight of $1.64 \pm 0.13 \mathrm{~g}$ were equally divided into the eight glass aquaria $(100 \mathrm{~L}$ each, duplicate per treatment). All aquaria were filled with well water. Four isonitrogenous $(45 \% \mathrm{CP})$ and isocaloric $20.0 \mathrm{MJ} \mathrm{GE} \mathrm{kg}{ }^{-1}$ test diets were formulated. A diet containing FM $\left(D_{1}\right)$ as the main source of protein was considered as the control diet. Three tested diets were partially $\left(20\left(D_{2}\right), 40\left(D_{3}\right)\right.$ and $\left.60 \%\left(D_{4}\right)\right)$ substituted for dietary FM protein from control diet with PBM, respectively. In a substitution experiment, the best feed conversion ratio (FCR) and survival rate were obtained with the $\mathrm{D}_{1}(100 \% \mathrm{FM})$, while protein effeciency ratio (PER), protein productive value (PPV) and energy retention (ER) were obtained with the $D_{1}$ and $D_{2}$. The present results indicate that without any significant effect on the PER, PPV and ER, PBM could be used as dietary alternative protein replacement of FM up to the level of $20 \%$ for European elver eels, A. anguilla.
\end{abstract}

Key words: alternative protein source, Anguilla anguilla eel, fish meal replacement

\section{Introduction}

Eels are essentially carnivorous with dietary protein requirement about $45 \%$. Fish meal is the dominant ingredient in commercially prepared diets for eel fish. As a consequence of rapid growth in fish and shellfish farming, fish meal prices have increased significantly in the past few years and are likely to increase further with continued growth in demand (Hardy \& Tacon 2002). As with general aquaculture nutrition, apriority area of major research is the reduction and possible elimination of fish meal and fish oil (Hardy \& Gatlin 2002). The uncertain future of fish meal availability and its potential high cost has forced to investigate alternative protein sources of good nutritional quality, which are ideally readily available and more cost effective than fish meal. This will reduce production costs and create a good quality product suitable for any small or largescale fish production system.

Poultry by-product meal (PBM) as rendered animal protein have considerable potential in fish and shrimp feeds (Bureau, et al. 2003; Goda et al. 2007; Burr et al. 2013). This animal by-product have long been used in compound feeds for terrestrial monogastric animals such as poultry and swine (Parsons \& Fisher-Vanden, 1997). Many studies in recent years have also shown that rendered animal protein ingredients are useful for fish feed formulation and comparatively less expensive than fish meal (Steffens, 1994; Rodriguez-Sena et al., 1996; Bureau et al., 1999; Abdel-Warith et al., 2001;
Samocha et al. 2004; Cruz-Suarez et al. 2007; Muralisankar and Bhavan 2013).

Relatively little research has been focused on dietary requirements of European eel, A. anguilla due to the critical problem in early age culture related to acceptance of artificial feed (weaning) compared other fish. Therefore, this study was designed to investigate the effect of partial substitution of dietary FM with three poultry by-product meal (PBM) inclusion levels $(20,40$ and $60 \%)$ on growth performance and feed utilization of European elver eel, A. anguilla .

\section{Material and methods}

\section{Fish Husbandry and Experimental Design}

The experiment was conducted at the Experimental Fish Farm at El-Kanater El-Khayria, National Institute of Oceanography and Fisheries (NIOF), Delta Barrage, Kalubiya Governorate, Egypt.

European elver eel, A. anguilla with an initial body weight of $1.64 \pm 0.13 \mathrm{~g}$ were obtained from the wild catch of Edku Lake, Alexandria Governorate, Egypt. The fish were stocked at a rate of 10 fish aquarium $^{-1}$ into eight indoor glass aquaria $(80 \times 40 \times 60 \mathrm{~cm}, 100 \mathrm{~L}$ each) representing the four experimental treatments, the control diet (100\% FM) and other three inclusion levels by PBM $(20,40,60 \%)$. Aquaria were supplemented with well water which was exchanged once daily after the second feeding time. 


\section{Experimental Diets}

All experimental diets were fed as wet paste Table 1 and 2. The daily ration was divided into two equal amounts and offered two times a day (8:00 and $14.00 \mathrm{~h}$ ). The fish were fed, one of four experimental diets, for 60 days. All fish $(100 \%)$ from each replicate were weighed every 10 days and the amount of daily allowance was adjusted accordingly.
Table 1. Chemical composition of diet ingredients.

Fish meal $\begin{gathered}\text { Poultry by- } \\ \text { product meal }\end{gathered}$

\begin{tabular}{lcc}
\hline Chemical analysis (determined on dry & matter basis) \\
\hline Dry Matter & 90 & 89 \\
Ether Extract & 13 & 13.1 \\
Crude protein & 66 & 68 \\
Total Carbohydrates & 1 & 2 \\
Ash & 10 & 5.9 \\
Gross Energy (Kcal/Kg) & 4966 & 5130 \\
\hline
\end{tabular}

Table 2. Composition and proximate analysis of the experimental diets

\begin{tabular}{|c|c|c|c|c|}
\hline \multicolumn{5}{|c|}{ Experimental diets } \\
\hline Ingredients & Diet $_{1}$ & Diet $_{2}$ & Diet $_{3}$ & Diet $_{4}$ \\
\hline Fish meal & 61 & 49 & 37 & 24 \\
\hline Poultry by-product meal & -- & 12 & 24 & 36 \\
\hline Corn gluten meal & 7 & 6 & 5 & 8 \\
\hline Wheat bran & 7 & 7 & 8 & 6 \\
\hline Corn starch & 14 & 15 & 15 & 15 \\
\hline $\mathrm{CMC}^{1}$ & 3 & 3 & 3 & 3 \\
\hline Fish oil & 2 & 2 & 2 & 2 \\
\hline Soybean oil & 2 & 2 & 2 & 2 \\
\hline Vit. \& Min. premix ${ }^{2}$ & 4 & 4 & 4 & 4 \\
\hline Vitamin C (g/Kg diet $)$ & 1 & 1 & 1 & 1 \\
\hline \multicolumn{5}{|c|}{ Chemical analysis (determined on dry matter basis) } \\
\hline Dry matter (DM) & 94.0 & 92.5 & 93.0 & 92.4 \\
\hline Crude protein $(\mathrm{CP})$ & 45.5 & 44.3 & 44.5 & 45.4 \\
\hline Digestible protein $(\mathrm{DP})^{3}$ & 34.24 & 33.00 & 29.62 & 28.33 \\
\hline Ether extract (EE) & 13.0 & 12.6 & 13.6 & 12.7 \\
\hline Total carbohydrate ${ }^{4}$ & 9.0 & 8.5 & 7.0 & 6.5 \\
\hline Ash & 26.5 & 27.1 & 27.9 & 27.4 \\
\hline $\mathrm{GE}\left(\mathrm{Mj} \mathrm{kg}^{-1} \operatorname{diet}^{-1}\right)^{5}$ & 20.38 & 20.11 & 20.70 & 20.55 \\
\hline $\mathrm{DE}\left(\mathrm{Mj} \mathrm{kg}^{-1} \operatorname{diet}^{-1}\right)^{6}$ & 15.02 & 14.98 & 14.25 & 13.65 \\
\hline $\mathrm{P} / \mathrm{E}$ ratio $\left(\mathrm{Kcal} \mathrm{kg}{ }^{-1} \operatorname{diet}^{-1}\right)$ & 93.39 & 92.12 & 89.92 & 92.59 \\
\hline Feed cost (LE.) $\mathrm{Kg}^{-1}$ gain & 34.40 & 35.27 & 65.8 & 105.1 \\
\hline \multicolumn{5}{|l|}{ Amino acid profile } \\
\hline Arginine & 6.56 & 6.47 & 6.20 & 5.80 \\
\hline Histidine & 2.42 & 2.29 & 2.10 & 1.90 \\
\hline Isoleucine & 4.62 & 4.49 & 4.23 & 4.01 \\
\hline Leucine & 8.21 & 7.95 & 7.45 & 7.31 \\
\hline Lysine & 7.40 & 6.91 & 6.21 & 5.34 \\
\hline Methionine & 2.98 & 2.76 & 2.45 & 2.15 \\
\hline phenylalanine & 4.15 & 3.96 & 3.66 & 3.45 \\
\hline Threonine & 4.18 & 4.00 & 3.70 & 3.38 \\
\hline Tryptophan & 1.10 & 1.04 & 0.96 & 0.84 \\
\hline Valine & 6.21 & 5.94 & 5.49 & 5.02 \\
\hline
\end{tabular}

1Carboxy methyl cellulous

2 Vitamins and minerals mixture each $2 \mathrm{Kg}$ of mixture content: Per kg mix: $4000000 \mathrm{IU}$ vitamin A, $480000 \mathrm{IU}$ vitamin D3, $40000 \mathrm{mg}$ vitamin E, $2400 \mathrm{mg}$ vitamin K3, $4000 \mathrm{mg}$ vitamin B1, $6000 \mathrm{mg}$ vitamin B2, $40000 \mathrm{mg}$ niacin, $10000 \mathrm{mg} \mathrm{Ca}-$ D-pantothenate, $4000 \mathrm{mg}$ vitamin B6, $10 \mathrm{mg}$ vitamin B12, $100 \mathrm{mg}$ D-biotin, $1200 \mathrm{mg}$ folic acid, $40000 \mathrm{mg}$ vitamin C ve $60000 \mathrm{mg}$ inositol, $23750 \mathrm{mg}$ Mn, $75000 \mathrm{mg}$ Zn, $5000 \mathrm{mg} \mathrm{Zn,} 2000 \mathrm{mg}$ Co, $2750 \mathrm{mg} \mathrm{I}, 100 \mathrm{mg} \mathrm{Se}, 200000 \mathrm{mg}$. 3, 6 Digestible protein (DP) and Digestible energy (DE, Mj kg-1 diet-1) calculated according to results of digestibility trails (Table 5).

4Total carbohydrate $=100-(\mathrm{CP}+\mathrm{EE}+\mathrm{Ash})$

5 Calculated using gross calorific values of $23.63,39.52$ and $17.15 \mathrm{kj}$ g-1 for protein, fat and carbohydrate, respectively according to Brett (1971). 


\section{Statistical Analysis}

Data were statistically analyzed by ANOVA using SAS ANOVA procedure (SAS Institute Inc., 2004).

\section{Result and Discussion}

Dietary protein supply is one of the major factors that influence the growth of fish. Like other fish species, the reported protein requirements of European eel are relatively high compared to terrestrial animals (NRC, 1993). The protein requirement of European eel is ranging from 30-48\% (Spannhof and Kuhne, 1977; Degani et al. 1985). Poultry products are becoming plentiful in countries with extensive chicken and turkey production industries such as Egypt. If this abundant and inexpensive source of protein could be substituted for fish meal, much less expensive fish feeds could be produced.

Chemical analysis of the experimental diets indicated that the formulated protein levels was achieved. Analyzed crude protein levels (\% as DM) in the diets were 45.5 (control diet); 44.5 ( $\left.\operatorname{diet}_{2}\right) ; 44.5$ $\left(\operatorname{diet}_{3}\right)$ and $45.4\left(\operatorname{diet}_{4}\right)$.
Differences in growth of the fish fed the experimental diets became apparent after 60 days of feeding where the mean weight of fish either control or $20 \%$ PBD diets were significantly higher $(\mathrm{P} \geq 0.05)$ than those fed other experimental diets. This difference persisted for the duration of the experiment Table. 3. Fish fed control diet showed the highest significant $(\mathrm{P} \geq 0.05)$ values for average daily gain and survival (\%) followed by eel fed $20 \%$ PBM diet. Dietary PBM level had a significant effect on eel weight gain, specific growth rate, survival $(\%)$ and feed conversion ratio. Replace dietary FM with PBM more than $20 \%$ for eel resulted in the lowest final body weight, specific growth rate, average daily gain and survival $(\%)$. The present results recorded for a daily weight gain values within the range of previous values reported of the same life stage. Gallagher and Degani, (1988) recorded an average daily gain for eel ranged between (0.01-0.024 g/ day) and (0.02-0.05 g/ day) where the initial weight were 1.42 and $2.4 \mathrm{~g}$, respectively. For eels with initial weight of $2.2 \mathrm{~g}$, Engin and Carter (2005) recorded an average daily gain of $0.01 \mathrm{~g} /$ day. Average daily weight gain ranging from 0.002 to $0.004 \mathrm{~g} /$ day was recorded for glass eel of initial weight $0.1 \mathrm{~g}$ (Okorie et al. 2007).

Table 3. Growth performances and survival (\%) of eel fed different experimental diets

\begin{tabular}{|c|c|c|c|c|c|}
\hline \multicolumn{6}{|c|}{ Experimental diets } \\
\hline & Diet $_{1}$ & Diet $_{2}$ & $\operatorname{Diet}_{3}$ & Diet $_{4}$ & $\mathrm{SE} \pm$ \\
\hline Initial body weight (g) & 1.66 & 1.63 & 1.65 & 1.61 & 0.13 \\
\hline Final body weight (g) & $4.11^{\mathrm{a}}$ & $3.63^{\mathrm{a}}$ & $2.39^{\mathrm{b}}$ & $1.98^{\mathrm{b}}$ & 0.18 \\
\hline $\begin{array}{l}\text { Average weight gain } \\
\text { (g/fish/day) }\end{array}$ & $0.040^{\mathrm{a}}$ & $0.033^{\mathrm{b}}$ & $0.012^{\mathrm{c}}$ & $0.006^{\mathrm{d}}$ & 0.03 \\
\hline Specific growth rate $(\% /$ day $)$ & $1.51^{\mathrm{a}}$ & $1.33^{\mathrm{a}}$ & $0.61^{\mathrm{b}}$ & $0.34^{\mathrm{b}}$ & 0.09 \\
\hline Survival rate $(\%)$ & $95^{\mathrm{a}}$ & $90^{\mathrm{b}}$ & $85^{\mathrm{c}}$ & $80^{\mathrm{d}}$ & 0.5 \\
\hline
\end{tabular}

Diet $_{1:}$ Control diet; Diet $_{2:}$ 20\% PBM diet; Diet $_{3:}$ 40\% PBM diet; Diet $_{4:}$ 60\% PBM diet.

$\mathrm{A}, \mathrm{b}, \ldots .$. etc. means that in the same row with different superscription are significantly different $(\mathrm{P} \leq 0.05)$.

* $\mathrm{SE} \pm$ standard error. Calculated from residual mean square in the analysis of variance.

The best feed conversion ratio (FCR) was recorded for eel fed the control diet. This FCR was significantly better $(\mathrm{P} \geq 0.05)$ than when eels were fed the higher dietary PBM level diets more than $20 \%$ Table 4. Fraga, et al. (2003); Luzzana, et al. (2003); Nielsen and Prouzet (2008) recorded FCR ranged between 4.5-10 for European eel, A. anguilla. while, was 3.64 for American eel, A. rostrata. The same trend was observed in the present results.

Protein productive value and energy retention values did not differed significantly between fish fed either control or $20 \%$ PBM diets, while the lowest values was recorded with increasing inclusion levels of PBM in elver diets (40 and $60 \%$ PBM) Table 4. The same trend was observed for protein efficiency ratio and feed intake.
By the end of the experiment, survival (\%) of eels fed control diet was higher than the other experimental diets. All mortalities observed were small eels (mean weight, $1.74 \mathrm{~g}$ ) that displayed bite marks on their bodies. Based on this, it is felt that the higher growth rate in the control experimental fish led to higher variation between large and small eels and, ultimately, more aggressive behaviour within these aquaria. Degani and Levanon (1983 and 1984) reported that the study of the initial feeding of the glass eel is difficult due to the different rates of growth due to distinguishable groups among glass eels, $A$. anguilla during the initial period. Glass eels that did not adapt to eat, lost weight and died (20\%). Glass eels adapted to culture conditions could be divided into three main groups: fast-growing elvers (3\% of the total sample), moderately fast-growing elvers $(25 \%)$ and the other $52 \%$ were slow-growing 
elvers (Degani 1986). Few studies dallied with PBM as protein source in eel fish diets. Degani et al. (1984) found that poultry by-products could be used to support growth of glass eels, Anguilla anguilla, but a more precise study is needed to find out the optimum dietary levels should be used in eel diets in the initial period.

Some other fish species with high protein requirement noticed for accepting PBM as fish meal substitution. Fowler, (1991) reported that PBM replaced $20 \%$ of dietary fish meal in juvenile fall Chinook salmon, Oncorhynchus tshawytscha successfully, while negative effect on weight gain and feed efficiencies values was associated with increasing substitution up to $30 \%$. The ability to replace fish meal up to $25 \%$ by poultry by-product meal, without causing reduction in growth performance, nutrient utilization and nitrogen retention was recorded for juvenile black sea turbot, Psetta maeotica (Yigit et al 2006). More dietary inclusion level of PBM for low protein requirement of fish species was suggested by many findings (up to $40 \%$ for African catfish, Clarias gariepinus by Abdel-warith et al. 2001; up to 66\% for major carp and rainbow trout Oncorhynchus mykiss by Cheng et al. (2002).

Amino acid profile of poultry by product meal could be one of the main limitations for more inclusion in eel diets. As with more inclusion of PBM in elver diets more unbalanced dietary amino acid profile occur, which lead to suppression in elver growth performance. It was reported that, amino acid addition to PBM can improve fish growth performance (Rawles et al., 2009). Lysine and methionine supplementation, helped to achieve complete replacement of fish meal by PBM in diet for hybrid striped bass (Rawles et al. 2009). The amino acid availability was higher for most of the essential amino acids from FM compared to PBM with the exception of therionin, histeden and methionine for hybrid striped bass (Gaylord and Rawles , 2005).

Table 4. Feed utilization of eel fed different experimental diets

\begin{tabular}{lccccc}
\hline & \multicolumn{3}{c}{ Experimental diets } & & \\
\hline & Diet $_{1}$ & Diet $_{2}$ & Diet $_{3}$ & Diet $_{4}$ & $\mathrm{SE}^{*}$ \\
\hline $\begin{array}{l}\text { Feed consumption } \\
\text { (g/day/fish) }\end{array}$ & 0.17 & 0.15 & 0.12 & 0.10 & 0.05 \\
$\begin{array}{l}\text { Feed conversion ratio } \\
\text { (g feed/g gain) }\end{array}$ & $4.08^{\mathrm{c}}$ & $4.58^{\mathrm{b}}$ & $9.51^{\mathrm{a}}$ & $16.98^{\mathrm{a}}$ & 0.51 \\
Protein efficiency ratio & $0.53^{\mathrm{a}}$ & $0.49^{\mathrm{a}}$ & $0.23^{\mathrm{b}}$ & $0.12^{\mathrm{b}}$ & 0.05 \\
Protein productive value & $8.12^{\mathrm{a}}$ & $7.34^{\mathrm{a}}$ & $3.55^{\mathrm{b}}$ & $1.86^{\mathrm{b}}$ & 0.40 \\
Energy retention\% & $11.91^{\mathrm{a}}$ & $11.16^{\mathrm{a}}$ & $6.28^{\mathrm{b}}$ & $5.39^{\mathrm{b}}$ & 0.64 \\
\hline
\end{tabular}

Diet $_{1:}$ Control diet; Diet 2: 20\% PBM diet; Diet $_{3:}$ 40\% PBM diet; Diet 4 : 60\% PBM diet.

$\mathrm{A}, \mathrm{b}, \ldots .$. .etc. means that in the same row with different superscription are significantly different $(\mathrm{P} \leq 0.05)$.

*SE \pm standard error. Calculated from residual mean square in the analysis of variance.

\section{Conclusion}

In a substitution experiment, the best feed conversion ratio (FCR) and survival rate were obtained with the $\mathrm{D}_{1}(100 \% \mathrm{FM})$, while protein effeciency ratio (PER), protein productive value (PPV) and energy retention (ER) were obtained with the $D_{1}$ and $D_{2}$. The present results indicate that without any significant effect on the PER, PPV and ER, PBM could be used as dietary alternative protein replacement of FM up to the level of $20 \%$ for European elver eels, A. anguilla.

\section{References}

Abdel-warith, A.A.; Russell, P.M. and Davies, S.J. (2001). Inclusion of a commercial poultry byproduct meal as a portion replacement of fish meal in practical diets for African catfish Clarias gariepinus (Burchell 1822). Aquaculture Research, 32(1):296-305.

Brett, J. R., (1971). Energetic responses of salmon to temperature. A study of some thermal relations in the physiology and fresh water ecology of sockeye salmon (Oncrhynchus nerka). American zoologist 11: 99-113.

Bureau, D. P.; Harris, A.M. and Cho, C.Y. (1999). Apparent digestibility of rendered animal protein ingredients for rainbow trout (Oncorhynchus mykiss). Aquaculture, 180: 345-358.

Bureau, D.P.; Gunther, S.J. and Cho, C.Y. (2003). Chemical composition and preliminary theoretical estimates of waste outputs of rainbow trout in commercial cage culture operations in Ontario. North Am. Aquaculture, 65: 33-38.

Burr, G.S., Wolters, W.R., Barrows, F.T. and Donkin, A.W. (2013). Evaluation of a canola protein concentrate as a replacement for fishmeal and poultry by-product meal in a commercial production diet for Atlantic salmon (Salmo salar). International Aquatic Research 2013, 5:5,http://www.intaquares.com/content/5/1/5.

Cheng, Z.J.; Behnke, K.C. and Dominy, W.G. (2002). Effects of poultry by-product meal as a substitute for fish meal in diets on growth and body composition of juvenile pacific white 
shrimp, Litopenaeus vannamei. Applied aquaculture, 12(1):71-83.

Cruz-Suárez, L.E. and Tapia-Salazar, M. (2007). Harina de kelp en manual de ingredients proteicos Y aditivos empleados en la formulación de alimentos balanceados para camarones peneidos. Ed. Tsai Garcia Galano, Humberto Villarreal colmenares Y Jorge L. fenucci.

Degani, G. (1986). Dietary effects of lipid source, lipid level and temperature on growth of glass eel (Anguilla anguilla). Aquaculture 56:207-214.

Degani, G. and Levanon, D. (1983). The influence of low density on food adaptation, cannibalism and growth of eels (Anguilla anguilla (L.) ) . Bamidgeh, 35: 53-60.

Degani, G. and Levanon, D. (1984). Influence of shapes of indoor and outdoor containers on adaptation to artificial food, growth and survival of elvers. Prog. Fish Cult., 46: 191-194.

Degani G.; Levanon, D. and Dosoretz, C. (1984). The growth of Anguilla anguilla (L.) in different densities in out-door containers with Oreochromis aurea. Prog. Fish. Cult. 47, 114-1 18.

Degani, G.; Horowitz, A. and Levanon, D. (1985). Effect of protein level in purified diet and of density, ammonia and 0 , level on growth of juvenile European eels (Anguilla anguilla L.). Aquaculture, 46: 193-200.

Engin, K. and Carter, C.G. (2005). Fish meal replacement by plant and animal by-products in dietd for the Australian short-finned eel, Anguilla australis (Richardson). Aquaculture Research, 36:445-454.

Fowler, L.G. (1991). Poultry by product meal as a dietary protein source in fall chinook salmon diets. Aquaculture, 99: 309-321.

Fraga, I.; Galindo, J.; Jaime, C.B. (2003). Requrimientos nutricionales en juveniles de Anguila (Anguilla rostrata): Evaluación de relactiones protein/enegia en la dieta Assessment of protein/energy ratio in diet. II congreso Iberoametricano vitual de Acui cultura, 936-944.

Gallagher, M.L. and Degani, G. (1988). Poultry meal and poultry oil as sources of protein and lipid in the diet of European eels (Anguilla anguilla). Aquaculture, 73:177-187.

Gaylord, T.G. and Rawles, S.D. (2005). The modification of poultry by-product meal for use in hybrid striped bass Morone chrysops x $M$. saxatilis diets. World aqu. Socie., 36(3):363-374.

Goda, A. M. ; El-Haroun, E. R. ; Kabir Chowdhury, M. A. (2007). Effect of totally or partially replacing fish meal by alternative protein sources on growth of African catfish Clarias gariepinus (Burchell, 1822) reared in concrete tanks. Aquac. Res., 38 (3): 279-287.

Hardy, R.W., Gatlin, D. (2002). Nutritional strategies to reduce nutrient losses in intensive aquaculture. In: Cruz-Suárez, L. E., Ricque-Marie, D., Tapia-
Salazar, M., Gaxiola-Cortés, M. G., Simoes, N. (Eds.). Avances en Nutrición Acuícola VI. Memorias del VI Simposium Internacional de Nutrición Acuícola. 3 al 6 de Septiembre del 2002. Cancún, Quintana Roo, México.

Hardy, R.W. and Tacon, A.G.J. (2002). Fish meal historical uses, production trends and future outlook for sustainable supplies. In R.R. Stickney (Ed.), sustainable Aquaculture, New York: CABI.

Luzzana, U.; Scolaria, M.; Campo Dall'Orto. B.; Caprino, F.; Turchini, G.; Orban, E.; Sinesio, F. and Valfre, F. (2003). Growth and product quality of European eel (Anguilla anguilla) as affected by dietary protein and lipid sources. J. Appl. Ichthyol., 19:74-78.

Muralisankar, T. and Saravana Bhavan, P. (2013). Chicken waste meal as an alternative for fishmeal for better survival and growth of the freshwater prawn Macrobrachium rosenbergii post larvae. Research Journal of Biotechnology, 8(2): 61-66.

Nielsen, T. and Prouzet, P. (2008). Capture-based aquaculture of the wild European eel (Anguilla anguilla). In A. Lovatelli and P.F. Holthus (eds). Capture-based aquaculture. Global overview. FAO Fisheries Technical Paper. No. 508. Rome, FAO. pp. 141-168.

NRC (National Research Council) 1993. Nutrient requirement of fishes. National Academy of Sciences. Washington, DC, 114pp.

Okarie, E.O., Kim, Y.C., Lee, S., Bae, J.Y., Yoo, J.H., Han, K. and Bai, S.C. (2007). Revaluation of the dietary protein requirements and optimum dietary protein to energy ratios in Japanese eel, Anguilla japonica.The world Aquaculture society, 38(3):418-426.

Parson, E. A. and Fisher-Vanden, K. (1997). 'Integrated Assessment Models of Global Climate Change', Ann. Rev. Energ. Env. 22, 589-628.

Rawles, S.D.; Gaylord, T.G.; Mc.Entire, M.E. and freeman, D.W. (2009). Evaluation of poultry byproduct meal in commercial diets for hybrid striped bass, Morone chrysops $q \times$ Morone saxatilis $\hat{\sigma}$, in Pond Production. World aquaculture society, 4(2):141-156.

Rodriguez-Sena, A. M.; Olivera, M. A. and Carmona-osalda, C. (1996). Nutritional value of animal by-product meal in practical diets for Nile tilapia Oreochromis niloticus (L) fry. Aquacult. Res., 27: 67-73.

Samocha, T.; Davis, D.A.; Saoud, I.P. and DeBault, K. (2004). Substitution of fish meal by coextruded soybean poultry by-product meal in practical diets for the Pacific white shrimp, Litopenaeus vannamei. Aquaculture, 231: 197203.

SAS Institute Inc. (2004). SAS/STAT User's Guide. Version 9.1, Cary, NC: SAS Institute Inc.

Spannhof, L. and Kuhne, H. (1977). Untersuchungen zur Verwertung verschiedener Futtermischungen 
durch europaische Aale (A. anguilla). Arch. Tiererniihr., 27: 517-531.

Steffens, W. 1994. Replacement of fish meal with poultry byproduct meal in diets for rainbow trout (Oncorhynchus mykiss). Aquaculture, 124: 2734.
Yigit, M.; Erdom, M.; Koshio, S.; Ergün, S.; Türker, A. and Karaali, B. (2006). Substitution fish meal with poultry by-product meal in diets for black sea turbot Pestta maeotica. Aquaculture nutrition, 12(5):340-347. 